\title{
The Way of the Dialetheist: Contradictions in Buddhism
}

Yasuo Deguchi

Kyoto University

Jay L. Garfield

Smith College, jgarfield@smith.edu

Graham Priest

University of Melbourne

Follow this and additional works at: https://scholarworks.smith.edu/phi_facpubs

Part of the Philosophy Commons

\section{Recommended Citation}

Deguchi, Yasuo; Garfield, Jay L.; and Priest, Graham, "The Way of the Dialetheist: Contradictions in Buddhism" (2008). Philosophy: Faculty Publications, Smith College, Northampton, MA.

https://scholarworks.smith.edu/phi_facpubs/20 


\section{UNIVERSITY of \\ HAWAI'I \\ PRESS}

The Way of the Dialetheist: Contradictions in Buddhism

Author(s): Yasuo Deguchi, Jay L. Garfield and Graham Priest

Source: Philosophy East and West, Vol. 58, No. 3 (Jul., 2008), pp. 395-402

Published by: University of Hawai'i Press

Stable URL: https://www.jstor.org/stable/20109479

Accessed: 03-08-2018 14:15 UTC

\section{REFERENCES}

Linked references are available on JSTOR for this article:

https://www.jstor.org/stable/20109479?seq=1\&cid=pdf-reference\#references_tab_contents

You may need to $\log$ in to JSTOR to access the linked references.

JSTOR is a not-for-profit service that helps scholars, researchers, and students discover, use, and build upon a wide range of content in a trusted digital archive. We use information technology and tools to increase productivity and facilitate new forms of scholarship. For more information about JSTOR, please contact support@jstor.org.

Your use of the JSTOR archive indicates your acceptance of the Terms \& Conditions of Use, available at https://about.jstor.org/terms

University of Hawai'i Press is collaborating with JSTOR to digitize, preserve and extend access to Philosophy East and West 
COMMENT AND DISCUSSION

The Way of the Dialetheist: Contradictions in Buddhism

Yasuo Deguchi

Kyoto University

\section{Jay L. Garfield}

Smith College, University of Melbourne, and Central Institute of Tibetan Studies

\section{Graham Priest}

Universities of Melbourne and St. Andrews

\section{Introduction}

Anyone who is accustomed to the view that contradictions cannot be true and cannot be accepted, and who reads texts in the Buddhist traditions, will be struck by the fact that these texts frequently contain contradictions. Just consider, for example:

(1)

Twenty years a pilgrim,

Footing east and west.

Back in Seiken,

I've not moved an inch. (Seiken Chiju, Poem)

(2)

Who says my poetry is poetry?

My poetry is not poetry.

Provided you understand my poetry as not poetry

Only then can we discourse together about poetry. (Ryōkan, Poem $)^{2}$

(3)

What the realised one has described as the possession of distinctive features is itself the non-possession of distinctive features. (Vajracchedika 5$)^{3}$

(4)

The very same perfection of insight, Subhuti, which the realised one has preached is indeed perfectionless. (Vajracchedika 13b) ${ }^{4}$

(5)

Furthermore, Subhuti, any perfection of acceptance the realised one has is indeed a nonperfection. (Vajracchedika 14e) ${ }^{5}$

(6)

Everything is real and is not real,

Both real and not real,

Neither real nor not real.

This is Lord Buddha's teaching. (MMK XVIII: 8$)^{6}$ 
(7)

Just understand that birth-and-death is itself nirvana. There is nothing such as birth and death to be avoided. There is nothing such as nirvana to be sought. Only when you realise this are you free from birth and death. (Dōgen, Shōji $)^{7}$

(8)

As all things are buddha-dharma, there is delusion and realisation, practice, birth and death, and there are buddhas and sentient beings. As the myriad things are without an abiding self, there is no delusion, no realization, no buddha, no sentient being, no birth and death. (Dōgen, Shōji $)^{8}$

(9)

Nothing $(m u)$ is absolutely contradictory and self-identical. From this point, every being (u) is being and at the same time nothing. (Nishida, "Preface" to Collected Philosophical Papers $)^{9}$

Some may argue that none of these contradictions is meant to be accepted as true, that each should, in fact, be interpreted in some other way. Others may argue that the contradictions are meant to be taken this way, but that this shows that the views espoused are some kind of irrational mysticism. The point of the present note is to examine the matter. We will argue that at least some contradictions found in the texts are indeed meant literally and to be accepted as true. We will also argue that this is not a mark of irrationality, but, indeed, a consequence of rationality itself. We will proceed by examining ways that contradictions may arise in Buddhist discourse.

\section{Contradictions not Meant to be Taken Literally}

Contradictions may sometimes be found in poetry in Buddhist traditions, for example in (1) and (2) above. In such contexts, it may be argued, plausibly, that they are not meant literally. They express something or other, but the poet no more means us to suppose that some contradiction is literally true than Shakespeare intends us to believe that Juliet is to be found by looking upwards at midday when Romeo tells us that she is the sun. The contradictions are just poetic license.

Consider the Seiken Chiju poem (1) above. The poet is not literally stating that he both traveled and did not travel. He is using the contradiction metaphorically to indicate that even though he has attained realization, the world he has realized is no different from the one about which he was ignorant; that although he has practiced long, in the context of all that is to be accomplished, that is as nothing; that while his steps may be conventionally real, they are ultimately empty; and perhaps more besides.

It might be suggested that contradictions in Buddhist discourse always function in this way: they are intended metaphorically or in some other nonliteral sense. But this cannot be maintained. Contradictions occur not just in Buddhist poetry, but in highly theoretical Buddhist texts in the middle of rigorous deductive arguments, for example those of Nāgārjuna (see 6 above). To suppose that they are metaphors just does not do justice to these texts. 
Another possibility is that a contradiction is meant literally, but not meant to be accepted. There are at least two sorts of context in which this may occur. Buddhists were well aware of the mode of argument called in the West reductio ad absurdum (in Sanskrit, this is called prasanga). Sometimes when contradictions occur in Buddhist texts, these are the conclusions of such arguments. For example in the $M M K$ Nāgārjuna argues against the self-existence of all things, and many of his arguments are reductio arguments. The self-existence of, for example, space as a primary element entails unacceptable contradictions. Space would either have characteristics or would lack them. If it lacks them, then it does not exist, since every existent has characteristics. But if it has them, it is not a primary element, since a primary element is what exists prior to any characteristics. So, the self-existence of space as a primary element entails that space does not exist as a primary element. ${ }^{10}$ Whether or not it works, this argument is clearly intended as a reductio of some kind.

But even in the $M M K$, contradictions do not always occur in contexts that are plausibly interpreted as the conclusions of reductio arguments. The example (6) above is most certainly not in a reductio context.

The Ch'an/Zen tradition provides a different kind of example of contradictions that are used literally, but not meant to be accepted as true. In some schools of $\mathrm{Ch}^{\prime}$ an/Zen, awakening can occur suddenly, and this sudden awakening can be triggered by a certain kind of shock. The shock that triggers awakening is often verbal, and in these cases it may well be that the shock is produced precisely by the contradictory content of an utterance. Zen practice is intended to enable us to transcend the reality constructed by our own conceptual thinking, and to enable us to perceive reality just as it is. Such transcendence may be triggered by coming to understand the inadequacy of conceptual thinking, and, it might be suggested, this can arise when we see that such thinking leads to irresoluble contradiction. This is one way to understand certain kōan exercises. Does a dog have Buddha nature? Yes, because all things have Buddha nature. No, because all things have no nature.

It may certainly be the case that some contradictions in Buddhist, and especially Zen, discourses function in this way; it can hardly be maintained that all do. This is simply because many contradictions do not occur in an immediately soteriological context; they occur in theoretical discourse about Buddhism, such as Nāgārjuna's MMK and Dōgen's Shōbōgenzō (see 6, 7, and 8 above). Contradictions in this context are not uttered simply for the psychological effect that they have on the listeners; in general, they are not intended to trigger fundamental psychological transformation.

Contradictions Meant Literally and to Be Accepted, but as Contextually Ambiguous

Some contradictions that can be found in Buddhist texts can be understood as having a certain kind of contextuality. Thus, it is often claimed that when helping people on the path to awakening, it is of no use to tell them things that, although true, they 
cannot understand, and which may even hinder their development. Better to tell them things that are only partially true, or that are even just plain false, if understanding these things takes them to a state where they are better placed to understand things more profound. In the same way, it is standard practice to teach people Newtonian mechanics before teaching relativity theory. Although the former is false, it would be very difficult to understand the latter if one did not have a good grasp of the more elementary theory.

This is the Buddhist stratagem referred to as upāya, of which much is made in the Lotus Sütra and other places. And it may be suggested that contradictions in Buddhist texts arise because different contradictory assertions are appropriate at different stages of Buddhist education (or history, since sometimes the doctrine of upāya is used by later Buddhist schools to account for the doctrines of earlier schools that are different from, and opposed to, their own). Thus, for example, it may be argued that it is perfectly acceptable to teach people that there is a Buddha, the four noble truths, the eightfold noble path, et cetera. As one may come to understand later, however, such things are, in a certain sense, distinctly misleading. A better understanding is achieved by denying all of these things, as does the Heart Sütra.

The device of upāya cannot account for many of the contradictions that occur in Buddhist texts, however. This is for the simple reason that contradictions are to be found located in documents meant for a single audience at a single time. Arguably, Nāgārjuna's $M M K$ is such a document. Even more clearly, each of Dōgen's lectures to his monks, as reproduced in the Shōbōgenzō, is like this. Indeed, one may sometimes find contradictory utterances located back-to-back in such discourses, for example as in (7) and (8) above. One can hardly take it that a context shift, of the kind necessary to make sense of an application of the doctrine of upāya, occurs in the space of a full stop.

A different, but related, way in which context can be used to defuse a literal contradiction concerns the doctrine of two truths or realities. Many Māhāyana Buddhists endorse the view that there is a conventional reality (truth) and an ultimate reality (truth). For some Buddhists - for instance, Vasubandhu, Sthiramati, and Gorampaconventional truth is something of an illusion. One may have to come to grips with some aspects of it in the process of upãya, but it is to be sloughed off in the process of awakening. For others, for example Nāgārjuna, Candrakīti, and Tsong khapa, the notion of conventional reality is more robust. Conventional truth is still truth, just different truth.

However one understands the two notions, one may obviously use them to defuse certain apparent contradictions. Some things, such as that there is a Buddha, a way, et cetera, are conventional truths; their contradictories-that there is no Buddha, no way, et cetera-are ultimate truths.

It is clear that some contradictions located in Buddhist texts should be understood in this way. This is certainly what Nāgārjuna has in mind when he says, in $M M K X V I I I: 6$, that it has been taught that there is a self, that there is no self, that there both is and is not a self, and that there is neither self nor nonself. Here a natural disambiguation reads this verse as saying simply that conventionally there is a self; 
ultimately there is not; there is conventionally, and there is not ultimately; that there neither is ultimately nor is not conventionally.

However, again, not all contradictions are of this kind. Thus, the most plausible understanding of some contradictions offered in the $M M K$, at least as interpreted by Candrakīrti, is that they express ultimate truths-notably, for example, in the claim that all things have the nature of emptiness, which is no nature. ${ }^{11}$ It is certainly an ultimate truth that all things are empty, and all things includes emptiness. (That is the doctrine of the emptiness of emptiness, adumbrated by Nāgārjuna and more explicitly by Candrakirti and those who follow his interpretation of the $M M K$ in India and Tibet, as well as by exegetes of Mādhyamaka such as Tsung Mi in China.) Emptiness in no essence, but is the lack of any essence, and is the essential quality of all things. It is hence the case, according to Mãdhyamaka philosophers and according to those who accept their doctrines, that ultimately things are essentially essenceless. This, while perhaps true, is contradictory. ${ }^{12}$

Before we leave the matter, one further point needs to be made. According to certain schools of Buddhism, especially Mādhyamaka, the distinction between conventional reality and ultimate reality-like all distinctions-is only conventional. From an ultimate perspective, there is no distinction between conventional reality and ultimate reality. The thought is taken to its logical conclusion in Zen, in which to live an awakened life is to lead a perfectly ordinary day-to-day existence (in a certain way). Now, if ultimately there is no distinction between conventional and ultimate reality, then the disambiguation provided by the distinction ultimately collapses. So the prima facie contradiction is more than just prima facie.

\section{Contradictions Meant to Be Taken Literally, and to Be Accepted, and as Unambiguous}

We have seen that there are various ways in which apparent contradictions in Buddhist discourses may be defused. And some contradictions, as we have seen, are best defused in this way. But we have also seen that contradictions may not always be defused by these mechanisms. Indeed, the discussion has taken us to the point of seeing why some contradictions in some Buddhist texts cannot be defused. To suppose that one ought to defuse them would be to misunderstand.

There are no ultimate truths. As we have put it before: "Ultimate truths are those about ultimate reality. But since everything is empty, there is no ultimate reality. There are, therefore, no ultimate truths. We can get at the same conclusion another way. To express anything in language is to express truth that depends on language, and so this cannot be an expression of the way that things are ultimately. All truths, then, are merely conventional." 13

If Buddhists were content merely to point mutely to ultimate reality, there would be nothing more to be said. But they are not. They explain how conventional reality is simply the imposition of conventional conceptual categories on ultimate reality, and they explain the delusion about the nature of ultimate reality to which this gives rise. In the very process, they describe certain things about ultimate reality. The in- 
describable is described; indeed, even to say that it is indescribable is to describe it. In this respect, Buddhism is akin to any of a number of positions that claim that there is an ineffable reality, and then go on to explain why this is so, in the process, saying things about that reality. The phenomenon is to be found, for example, in Neoplatonism, in Advaita Vedānta, and in Heidegger on Being. ${ }^{14}$

It could be said that such descriptions are simply upāya, to be jettisoned as soon as one can appreciate the nature of ultimate reality directly. Although they might be seen in this way, this would not do justice to the texts. The texts in question are simply too carefully reasoned and too explicit, and are read by their commentators as correct. There is indeed a difference recognized in all Māhāyana Buddhist traditions between, on the one hand, the conceptually mediated, and hence indirect, apprehension of ultimate reality that one obtains through reasoning and discursive practices, and, on the other hand, the immediate, direct, perception of emptiness that is the goal of meditative practice. However, the object of these two modes of apprehension is the same: emptiness, which is identical with dependent origination-the ultimate truth, which is in turn identical with the conventional truth properly understood. The descriptions of ultimate reality, however thin they may be, and however imperfectly they capture the object of yogic direct perception, are, nonetheless, taken to be veridical. And again, since the things claimed about ultimate reality are often contradictory to things claimed about conventional reality, if these two things are ultimately the same reality it is a contradictory one.

It might be suggested that although such contradictions are true, their truth is incomprehensible. Such truths, in this view, have the deictic function of ostending the incomprehensibility of ultimate reality, but cannot themselves be understood. This view concedes our point that such contradictions are intended as true, but we do not concede the view that they are incomprehensible. Those who hold that contradictions are always and obviously only false will of course find supposing them to be true incomprehensible. However, despite various orthodoxies, East and West, the view that some contradictions are true is a perfectly coherent and intelligible view, as modern studies in dialetheism and paraconsistency have established. ${ }^{15}$

Let us end with a few words about reductio ad absurdum. We noted that this mode of argument is well recognized in Buddhist logic. Indeed, it is orthodox in logic since at least Dignāga and Dharmarkīti in the seventh century. Since this inference depends on the rejection of contradictions, then surely, one might argue, no interpretation of Buddhism that accepts contradictions can be correct.

Matters are not that straightforward. There are certainly groups of Buddhists who accept the authority of Dharmarkiti on the matter, and who therefore would accept no interpretation of Buddhism that endorses contradictions. However, there is an older doctrine going back to the time of the Buddha himself. This is the catuhskoti: a doctrine to the effect that with respect to any claim there are four possibilities: that it is true (only), false (only), both true and false, or neither true nor false. And Nāgārjuna, for example, often argues taking these four possibilities explicitly into account. Hence, in certain older traditions, and the traditions not so influenced by Dharmarkīti's logic, there is no legitimate presumption of consistency. 
This leaves an obvious question as to how Buddhist thinkers of this kind, such as Nāgārjuna, can employ reductio arguments. A full answer to this is no doubt complex, but, in brief, contradictions are perfectly acceptable in some contexts but not in others. Reductio ad absurdum is not reductio ad contradictionem. Some contradictions may not be absurd, and not all absurdities are contradictions-and what is taken to be absurd by one theorist may be different from what is taken to be absurd by another. In Indian debate logic, a reductio succeeds when the opponent is forced to concede a consequence that is unacceptable by their own lights, whether or not it is contradictory. If a contradiction is unacceptable, it will function as the anvil of a reductio; if not, it will not.

\section{Conclusion}

To summarize, we have seen why even serious theoretical Buddhist texts may be expected to contain contradictions. Such contradictions are integral to certain core Buddhist, or at least Māhāyana, views. Nor is this some kind of irrationalism. The contradictions follow from some of the most fundamental postulates of Buddhism. It does mean, though, that Buddhisms of certain kinds are committed to dialetheism, the view that some contradictions are true. Those who take that adherence to the Law of Non-Contradiction is a necessary condition for rationality may well conclude that, to this extent, such Buddhisms are irrational. But modern developments in paraconsistent logics have taught us that one need not draw this conclusion. Buddhism can be rational although inconsistent-indeed, ultra-rational, since the contradictions are the result of following a certain view of the world through to its logical conclusions.

Notes

1 - Zen Poems: Let the Spring Breeze Enter, trans. L. Stryk and T. Ikemoto (New York: Grove Press, 1995), p. xxxi.

2 - An Anthology of Ryōkan's Poetry, ed. and trans. Y. Iriya (Tokyo: Kodansha, 1982), p. 178.

3 - P. Harrison, "Vajracchedikā Prajñāpāramitā: A New English Translation of the Sanskrit Text Based on Two Manuscripts from Greater Gandhāra," forthcoming in J. Braarvig, ed., Manuscripts in the Schōyen Collection VII: Buddhist Manuscripts, vol. 3 (Oslo: Hermes Publishing, 2006).

4 - Ibid.

5 - Ibid.

6 - The Fundamental Wisdom of the Middle Way: Nāgārjuna's Mūlamadhyamakakārikā, trans. J. Garfield (New York: Oxford University Press, 1995); hereafter $M M K$. 
7 - Moon in a Dewdrop: Writings of Zen Master Dōgen, trans. K. Takahashi (San Francisco: North Point Press, 1985), p. 74.

8 - lbid., p. 69.

9 - Nishida Kitarō, Nishida's Collected Works, Vol. 9 (Collected Philosophical Papers, Vol. 3), (Tokyo: Iwanami Shoten, 1988), p. 6; passage translated by Y. Deguchi.

$10-M M K V$.

11 - See especially the Prasannapadā discussion of $M M K X V: 8, X V I I: 8$, and XXIV : 18-19.

12 - For a more extended discussion of this issue, see J. Garfield and G. Priest, "Nāgārjuna and the Limits of Thought," Philosophy East and West 53 (1) (2003): 1-21, reprinted in J. Garfield, Empty Words (New York: Oxford University Press, 2002), pp. 86-108, and in G. Priest, Beyond the Limits of Thought, 2nd ed. (Oxford: Oxford University Press, 2002), chap. 16.

13 - Garfield and Priest, "Nāgārjuna and the Limits of Thought," sec. 5. There is another route to this same conclusion. Buddhism is resolutely nominalist with regard to universals. According to the standard Buddhist view of language and thought, words and thoughts engage directly with universals, which, on analysis, are nonexistent in reality, by virtue of their causal inefficacy and their permanence. Conceptual thought and language therefore always superimpose something nonexistent upon reality, and therefore can never accurately represent reality as it is ultimately. (See Garfield, "Why did Bodhidharma Go to the East? Buddhism's Struggle with Mind in the World," Sophia 45:2, pp. 61-80, 2006.)

14 - See, further, G. Priest, "The Limits of Language," in K. Brown, ed., Encyclopedia of Language and Linguistics, 2nd ed. (Amsterdam: Elsevier, 2005), vol. 7, pp. 156-159.

15 - See, e.g., Priest, Beyond the Limits of Thought. For paraconsistent logic in general, see G. Priest, "Paraconsistent Logic," in D. Gabbay and F. Guenthner, eds., Handbook of Philosophical Logic, 2nd ed. (Dordrecht: Kluwer Academic Publishers, 2002), vol. 6, pp. 287-393. 